\title{
Glomerulonefritis Akut Pasca Streptokokus pada Anak
}

\author{
Sondang Maniur Lumbanbatu
}

\begin{abstract}
Glomerulonefritis merupakan penyakit ginjal dengan suatu inflamasi dan proliferasi sel glomerulus. Peradangan tersebut terutama disebabkan mekanisme imunologis yang menimbulkan kelainan patologis glomerulus dengan mekanisme yang masih belum jelas. Pada anak kebanyakan kasus glomerulonefritis akut adalah pasca infeksi, paling sering infeksi streptokokus beta hemolitikus grup A. Dari perkembangan teknik biopsi ginjal per-kutan, pemeriksaan dengan mikroskop elektron dan imunofluoresen serta pemeriksaan serologis, glomerulonefritis akut pasca streptokokus telah diketahui sebagai salah satu contoh dari penyakit kompleks imun. Penyakit ini merupakan contoh klasik sindroma nefritik akut dengan awitan gross hematuria, edema, hipertensi dan insufisiensi ginjal akut. Walaupun penyakit ini dapat sembuh sendiri dengan kesembuhan yang sempurna, pada sebagian kecil kasus dapat terjadi gagal ginjal akut sehingga memerlukan pemantauan.
\end{abstract}

Kata kunci: glomerulonefritis akut, Streptococcus beta hemolyticus group $A$, hematuria.

D i negara berkembang, glomerulon akut pasca infeksi streptokokus (GNAPS) masih sering dijumpai dan merupakan penyebab lesi ginjal non supuratif terbanyak pada anak. ${ }^{1}$ Sampai saat ini belum diketahui faktor-faktor yang menyebabkan penyakit ini menjadi berat, karena tidak ada perbedaan klinis dan laboratoris antara pasien yang jatuh ke dalam gagal ginjal akut (GGA) dan yang sembuh sempurna. ${ }^{2}$ Manifestasi klinis yang bervariasi menyebabkan insiden penyakit ini secara statistik tidak dapat ditentukan. ${ }^{3}$ Diperkirakan insiden berkisar 028\% pasca infeksi streptokokus. ${ }^{4,5}$ Pada anak GNAPS paling sering disebabkan oleh Streptococcus beta hemolyticus group $A$ tipe nefritogenik. ${ }^{6,7}$ Tipe antigen protein $M$ berkaitan erat dengan tipe nefritogenik. ${ }^{8,9}$ Serotipe streptokokus beta hemolitik yang paling sering dihubungkan dengan glomerulonefritis akut (GNA) yang didahului faringitis adalah tipe 12, tetapi kadang-

\section{Alamat korespondensi:}

Dr. Sondang Maniur Lumbanbatu

Bagian Ilmu Kesehatan Anak FK USU/RS HAM

Jalan Bunga Lau No. 17, Medan.

Telepon: 061-8361721, Fax.: 061-8361721. kadang juga tipe $1,4,6$ dan 25. Tipe 49 paling sering dijumpai pada glomerulonefritis yang didahului infeksi kulit / pioderma, walaupun galur 53,55,56,57 dan 58 dapat berimplikasi. ${ }^{10-13}$ Protein streptokokus galur nefritogenik yang merupakan antigen antara lain endostreptosin, antigen presorbing (PA-Ag), nephritic strain-associated protein (NSAP) yang dikenal sebagai streptokinase dan nephritic plasmin binding protein (NPBP), ${ }^{2,14}$

Glomerulonefritis akut pasca infeksi streptokokus dapat terjadi secara epidemik atau sporadik, 15 paling sering pada anak usia sekolah yang lebih muda, antara 5-8 tahun.5 Perbandingan anak laki-laki dan anak perempuan $2: 1 .{ }^{3}$ Di Indonesia, penelitian multisenter selama 12 bulan pada tahun 1988 melaporkan 170 orang pasien yang dirawat di rumah sakit pendidikan, terbanyak di Surabaya $(26,5 \%)$ diikuti oleh Jakarta $(24,7 \%)$, Bandung (17,6\%), dan Palembang (8,2\%). Perbandingan pasien laki-laki dan perempuan 1,3:1 dan terbanyak menyerang anak usia 6-8 tahun $(40,6 \%)^{2,3}$

\section{Patogenesis dan Gambaran Histologis}

Patogenesis GNAPS belum diketahui dengan pasti. ${ }^{2,4}$ 
Faktor genetik diduga berperan dalam terjadinya penyakit dengan ditemukannya HLA-D dan HLADR. ${ }^{3}$ Periode laten antara infeksi streptokokus dengan kelainan glomerulus menunjukkan proses imunologis memegang peran penting dalam mekanisme penyakit. Diduga respon yang berlebihan dari sistim imun pejamu pada stimulus antigen dengan produksi antibodi yang berlebihan menyebabkan terbentuknya kompleks Ag-Ab yang nantinya melintas pada membran basal glomerulus. Disini terjadi aktivasi sistim komplemen yang melepas substansi yang akan menarik neutrofil. Enzim lisosom yang dilepas netrofil merupakan faktor responsif untuk merusak glomerulus. ${ }^{2,4,10}$ Hipotesis lain adalah neuraminidase yang dihasilkan oleh streptokokus akan mengubah IgG endogen menjadi autoantigen. Terbentuknya autoantibodi terhadap IgG yang telah berubah tersebut, mengakibatkan pembentukan komplek imun yang bersirkulasi, kemudian mengendap dalam ginjal.13,16 Pada kasus ringan, pemeriksaan dengan mikroskop cahaya menunjukkan kelainan minimal. Biasanya terjadi proliferasi ringan sampai sedang dari sel mesangial dan matriks. Pada kasus berat terjadi proliferasi sel mesangial, matriks dan sel endotel yang difus disertai infiltrasi sel polimorfonuklear dan monosit, serta penyumbatan lumen kapiler. ${ }^{2,13}$ Istilah glomerulonefritis proliferatif eksudatif endokapiler difus digunakan untuk menggambarkan kelainan morfologi penyakit ini. ${ }^{3}$ Bentuk bulan sabit dan inflamasi interstisial dapat dijumpai mulai dari yang halus sampai kasar yang tipikal di dalam mesangium dan di sepanjang dinding kapiler. Endapan imunoglobulin dalam kapiler glomerulus didominasi oleh Ig $\mathrm{G}$ dan sebagian kecil Ig $M$ atau Ig A yang dapat dilihat dengan mikroskop imunofluoresen. Mikroskop elektron menunjukkan deposit padat elektron atau humps terletak di daerah subepitelial yang khas dan akan beragregasi menjadi Ag-Ab kompleks. ${ }^{10,16}$

\section{Gambaran Klinis}

Lebih dari $50 \%$ kasus GNAPS adalah asimtomatik. ${ }^{11}$ Kasus klasik atau tipikal diawali dengan infeksi saluran napas atas dengan nyeri tenggorok dua minggu mendahului timbulnya sembab. ${ }^{1}$ Periode laten ratarata 10 atau 21 hari setelah infeksi tenggorok atau kulit. $^{10}$

Hematuria dapat timbul berupa gross hematuria maupun mikroskopik. ${ }^{17,18}$ Gross hematuria terjadi pada $30-50 \%$ pasien yang dirawat. ${ }^{2}$ Variasi lain yang tidak spesifik bisa dijumpai seperti demam, malaise, nyeri, nafsu makan menurun, nyeri kepala, atau lesu. ${ }^{1,4}$ Pada pemeriksaan fisis dijumpai hipertensi pada hampir semua pasien GNAPS, biasanya ringan atau sedang. ${ }^{7,15}$ Hipertensi pada GNAPS dapat mendadak tinggi selama 3-5 hari. Setelah itu tekanan darah menurun perlahan-lahan dalam waktu 1-2 minggu. ${ }^{2,13}$ Edema bisa berupa wajah sembab, edem pretibial atau berupa gambaran sindrom nefrotik. ${ }^{10,11}$ Asites dijumpai pada sekitar $35 \%$ pasien dengan edem. ${ }^{1,4,13}$ Bendungan sirkulasi secara klinis bisa nyata dengan takipne dan dispne. ${ }^{2,3,5}$ Gejala gejala tersebut dapat disertai oliguria sampai anuria karena penurunan laju filtrasi glomerulus (LFG). ${ }^{1,10}$

\section{Laboratorium}

Pemeriksaan urin sangat penting untuk menegakkan diagnosis nefritis akut. Volume urin sering berkurang dengan warna gelap atau kecoklatan seperti air cucian daging. ${ }^{2,3}$ Hematuria makroskopis maupun mikroskopis dijumpai pada hampir semua pasien. ${ }^{10,12}$ Eritrosit khas terdapat pada $60-85 \%$ kasus, menunjukkan adanya perdarahan glomerulus. ${ }^{2,19}$ Proteinuria biasanya sebanding dengan derajat hematuria dan ekskresi protein umumnya tidak melebihi $2 \mathrm{gr} / \mathrm{m} 2$ luas permukaan tubuh perhari. Sekitar 2-5\% anak disertai proteinuria masif seperti gambaran nefrotik. ${ }^{1,2,5}$

Umumnya LFG berkurang, disertai penurunan kapasitas ekskresi air dan garam, menyebabkan ekspansi volume cairan ekstraselular. Menurunnya LFG akibat tertutupnya permukaan glomerulus dengan deposit kompleks imun. ${ }^{2,5}$ Sebagian besar anak yang dirawat dengan GNA menunjukkan peningkatan urea nitrogen darah dan konsentrasi serum kreatinin.,12

Anemia sebanding dengan derajat ekspansi volume cairan esktraselular dan membaik bila edem menghilang. ${ }^{4,5}$ Beberapa peneliti melaporkan adanya pemendekan masa hidup eritrosit. ${ }^{2,4}$ Kadar albumin dan protein serum sedikit menurun karena proses dilusi dan berbanding terbalik dengan jumlah deposit imun kompleks pada mesangial glomerulus. ${ }^{2,4}$

Bukti yang mendahului adanya infeksi streptokokus pada anak dengan GNA harus diperhatikan termasuk riwayatnya. Pemeriksaan bakteriologis apus tenggorok atau kulit penting untuk isolasi dan 
identifikasi streptokokus. ${ }^{1,2}$ Bila biakan tidak mendukung, dilakukan uji serologi respon imun terhadap antigen streptokokus. Peningkatan titer antibodi terhadap streptolisin-O (ASTO) terjadi 1014 hari setelah infeksi streptokokus. ${ }^{15,18}$ Kenaikan titer ASTO terdapat pada $75-80 \%$ pasien yang tidak mendapat antibiotik. ${ }^{5,11}$ Titer ASTO pasca infeksi streptokokus pada kulit jarang meningkat dan hanya terjadi pada 50\% kasus. ${ }^{10,12}$ Titer antibodi lain seperti antihialuronidase (Ahase) dan anti deoksiribonuklease B (DNase B) umumnya meningkat. Pengukuran titer antibodi yang terbaik pada keadaan ini adalah terhadap antigen DNase B yang meningkat pada $90-95 \%$ kasus. $^{2}$ Pemeriksaan gabungan titer ASTO, Ahase dan ADNase B dapat mendeteksi infeksi streptokokus sebelumnya pada hampir $100 \%$ kasus. $^{12}$

Penurunan komplemen C3 dijumpai pada 80-90\% kasus dalam 2 minggu pertama, sedang kadar properdin menurun pada 50\% kasus. Penurunan C3 sangat nyata, dengan kadar sekitar $20-40 \mathrm{mg} / \mathrm{dl}$ (normal $80-170 \mathrm{mg} / \mathrm{dl}$ ). ${ }^{4,10}$ Kadar IgG sering meningkat lebih dari $1600 \mathrm{mg} / 100 \mathrm{ml}$ pada hampir 93\% pasien.11 Pada awal penyakit kebanyakan pasien mempunyai krioglobulin dalam sirkulasi yang mengandung $\operatorname{IgG}$ atau IgG bersama-sama IgM atau C3. ${ }^{11,13}$

Hampir sepertiga pasien menunjukkan pembendungan paru. ${ }^{1,2}$ Penelitian Albar dkk., di Ujung Pandang pada tahun 1980-1990 pada 176 kasus mendapatkan gambaran radiologis berupa kardiomegali $84,1 \%$, bendungan sirkulasi paru $68,2 \%$ dan edem paru 48,9\%. Gambaran tersebut lebih sering terjadi pada pasien dengan manifestasi klinis disertai edem yang berat. ${ }^{20}$ Foto abdomen menunjukkan kekaburan yang diduga sebagai asites. ${ }^{1}$

\section{Diagnosis}

Kecurigaan akan adanya GNAPS dicurigai bila dijumpai gejala klinis berupa hematuria nyata yang timbul mendadak, sembab dan gagal ginjal akut setelah infeksi streptokokus. Tanda glomerulonefritis yang khas pada urinalisis, bukti adanya infeksi streptokokus secara laboratoris dan rendahnya kadar komplemen C3 mendukung bukti untuk menegakkan diagnosis. ${ }^{3}$ Tetapi beberapa keadaan dapat menyerupai GNAPS seperti: ${ }^{10}$

- Glomerulonefritis kronik dengan eksaserbasi akut

- Purpura Henoch-Schoenlein yang mengenai ginjal
- Hematuria idiopatik

- Nefritis herediter (sindrom Alport)

- Lupus eritematosus sistemik

\section{Tata laksana}

Penanganan pasien adalah suportif dan simtomatik. 12 Perawatan dibutuhkan apabila dijumpai penurunan fungsi ginjal sedang sampai berat ( klirens kreatinin < $60 \mathrm{ml} / 1 \mathrm{menit} / 1,73 \mathrm{~m} 2)$, BUN > $50 \mathrm{mg}$, anak dengan tanda dan gejala uremia, muntah, letargi, hipertensi ensefalopati, anuria atau oliguria menetap.12,13 Pasien hipertensi dapat diberi diuretik atau anti hipertensi. ${ }^{2,3}$ Bila hipertensi ringan (tekanan darah sistolik 130 $\mathrm{mmHg}$ dan diastolik $90 \mathrm{mmHg}$ ) umumnya diobservasi tanpa diberi terapi.5,12 Hipertensi sedang (tekanan darah sistolik $>140-150 \mathrm{mmHg}$ dan diastolik $>100 \mathrm{mmHg}$ ) diobati dengan pemberian hidralazin oral atau intramuskular (IM), nifedipin oral atau sublingual. ${ }^{1,2}$ Dalam prakteknya lebih baik merawat inap pasien hipertensi 1-2 hari daripada memberi anti hipertensi yang lama. Pada hipertensi berat diberikan hidralazin $0,15-0,30 \mathrm{mg} / \mathrm{kbBB}$ intravena, dapat diulang setiap 2-4 jam atau reserpin $0,03-0,10 \mathrm{mg} / \mathrm{kgBB}(1-3 \mathrm{mg} / \mathrm{m} 2)$ iv, atau natrium nitroprussid 1-8 m/kgBB/menit. Pada krisis hipertensi (sistolik $>180 \mathrm{mmHg}$ atau diastolik $>120 \mathrm{mmHg}$ ) diberi diazoxid $2-5 \mathrm{mg} / \mathrm{kgBB}$ iv secara cepat bersama furosemid $2 \mathrm{mg} / \mathrm{kgBB}$ iv. Plihan lain, klonidin drip $0,002 \mathrm{mg} / \mathrm{kgBB} / \mathrm{kali}$, diulang setiap 4-6 jam atau diberi nifedipin sublingual $0,25-0,5 \mathrm{mg} / \mathrm{kgBb}$ dan dapat diulang setiap 6 jam bila diperlukan. ${ }^{2,5,12}$

Retensi cairan ditangani dengan pembatasan cairan dan natrium. ${ }^{2,3,12}$ Asupan cairan sebanding dengan invensible water loss $(400-500 \mathrm{ml} / \mathrm{m} 2$ luas permukaan tubuh/hari) ditambah setengah atau kurang dari urin yang keluar. Bila berat badan tidak berkurang diberi diuretik seperti furosemid $2 \mathrm{mg} /$ kgBB, 1-2 kali/hari. ${ }^{1,2}$ Pemakaian antibiotik tidak mempengaruhi perjalanan penyakit. Namun, pasien dengan biakan positif harus diberikan antibiotik untuk eradikasi organisme dan mencegah penyebaran ke individu lain. ${ }^{2}$ Diberikan antimikroba berupa injeksi benzathine penisilin $50.000 \mathrm{U} / \mathrm{kg}$ BB IM atau eritromisin oral $40 \mathrm{mg} / \mathrm{kgBB} /$ hari selama 10 hari bila pasien alergi penisilin. ${ }^{10,12}$ Pembatasan bahan makanan tergantung beratnya edem, gagal ginjal, dan hipertensi. Protein tidak perlu dibatasi bila kadar urea 
$\mathrm{N}$ kurang dari $75 \mathrm{mg} / \mathrm{dL}$ atau $100 \mathrm{mg} / \mathrm{dL}$. Bila terjadi azotemia asupan protein dibatasi $0,5 \mathrm{~g} / \mathrm{kgBB} / \mathrm{hari}$. Pada edem berat dan bendungan sirkulasi dapat diberikan $\mathrm{NaCl} 300 \mathrm{mg} /$ hari sedangkan bila edem minimal dan hipertensi ringan diberikan $1-2 \mathrm{~g} / \mathrm{m} 2 /$ hari. Bila disertai oliguria, maka pemberian kalium harus dibatasi. ${ }^{2,12}$ Anuria dan oliguria yang menetap, terjadi pada 5-10\% anak. ${ }^{4,6}$ Penanganannya sama dengan GGA dengan berbagai penyebab dan jarang menimbulkan kematian. ${ }^{1,5}$

\section{Biopsi ginjal}

Pada GNAPS biopsi ginjal tidak diindikasikan. Biopsi dipertimbangkan bila,, 10

- Gangguan fungsi ginjal berat khususnya bila etiologi tidak jelas (berkembang menjadi gagal ginjal atau sindrom nefrotik).

- Tidak ada bukti infeksi streptokokus

- Tidak terdapat penurunan kadar komplemen

- Perbaikan yang lama dengan hipertensi yang menetap, azotemia, gross hematuria setelah 3 minggu, kadar C3 yang rendah setelah 6 minggu, proteinuria yang menetap setelah 6 bulan dan hematuria yang menetap setelah 12 bulan.

\section{Perjalanan Penyakit / Pemantauan}

Fase awal glomerulonefritis akut berlangsung beberapa hari sampai 2 minggu. Setelah itu anak akan merasa lebih baik, diuresis lancar, edem dan hipertensi hilang, LFG kembali normal. ${ }^{3,4,7}$ Penyakit ini dapat sembuh sendiri, jarang berkembang menjadi kronik. ${ }^{2}$ Kronisitas dihubungkan dengan awal penyakit yang berat dan kelainan morfologis berupa hiperselularitas lobulus. ${ }^{12,21}$

Pasien sebaiknya kontrol tiap 4-6 minggu dalam 6 bulan pertama setelah awitan nefritis. Pengukuran tekanan darah, pemeriksaan eritrosit dan protein urin selama 1 tahun lebih bermanfaat untuk menilai perbaikan.1,5 Kadar C3 akan kembali normal pada 95\% pasien setelah 8-12 minggu, edem membaik dalam 5-10 hari, tekanan darah kembali normal setelah 2-3 minggu, walaupun dapat tetap tinggi sampai 6 minggu. ${ }^{11}$

Gross hematuria biasanya menghilang dalam 1-3 minggu, hematuria mikroskopik menghilang setelah 6 bulan, namun dapat bertahan sampai 1 tahun., ${ }^{4,12}$
Proteinuria menghilang 2-3 bulan pertama atau setelah 6 bulan. Pearlman dkk, di Minnesota menemukan $17 \%$ dari 61 pasien dengan urinalisis rutin abnormal selama 10 tahun pemantauan. Ketidaknormalan tersebut meliputi hematuria atau proteinuria mikroskopik sendiri-sendiri atau bersama-sama. Dari 16 spesimen biopsi ginjal tidak satupun yang menunjukkan karakteristik glomerulonefritis kronik. ${ }^{21}$ Penelitian Potter dkk, di Trinidad, menjumpai 1,8\% pasien dengan urin abnormal pada 4 tahun pertama tetapi hilang 2 tahun kemudian dan 1,4\% pasien dengan hipertensi. Hanya sedikit urin dan tekanan darah yang abnormal berhubungan dengan kronisitas GNAPS..$^{22}$ Nissenson dkk, mendapatkan kesimpulan yang sama selama 7-12 tahun penelitian di Trinidad. ${ }^{23}$ Hoy dkk, menemukan mikroalbuminuria 4 kali lebih besar pada pasien dengan riwayat GNAPS, 24 sedangkan Potter dkk di Trinidad, menemukan 3,5\% dari 354 pasien GNAPS mempunyai urin abnormal yang menetap dalam $12-17$ tahun pemantauan. ${ }^{25}$ Penelitian White $\mathrm{dkk}$, menemukan albuminuria yang nyata dan hematuria masing-masing pada $13 \%$ dan $21 \%$ dari 63 pasien selama 6-18 tahun pemantauan. ${ }^{26}$ Kemungkinan nefritis kronik harus dipertimbangkan bila dijumpai hematuria bersama-sama proteinuria yang bertahan setelah 12 bulan. ${ }^{5}$

\section{Prognosis}

Berbagai faktor memegang peran dalam menetapkan prognosis GNAPS antara lain umur saat serangan, derajat berat penyakit, galur streptokukus tertentu, pola serangan sporadik atau epidemik, tingkat penurunan fungsi ginjal dan gambaran histologis glomerulus. ${ }^{11,24}$ Anak kecil mempunyai prognosis lebih baik dibanding anak yang lebih besar atau orang dewasa oleh karena GNAPS pada dewasa sering disertai lesi nekrotik glomerulus. ${ }^{2,3}$

Perbaikan klinis yang sempurna dan urin yang normal menunjukkan prognosis yang baik. ${ }^{25}$ Insiden gangguan fungsi ginjal berkisar 1-30\%. Kemungkinan GNAPS menjadi kronik 5-10 \%; sekitar 0,5-2\% kasus menunjukkan penurunan fungsi ginjal cepat dan progresif dan dalam beberapa minggu atau bulan jatuh ke fase gagal ginjal terminal. ${ }^{18}$ Angka kematian pada GNAPS bervariasi antara $0-7 \%{ }^{2,21}$ Melihat GNAPS masih sering dijumpai pada anak, maka penyakit ini harus dicegah karena berpotensi menyebabkan 
kerusakan ginjal. Pencegahan dapat berupa perbaikan ekonomi dan lingkungan tempat tinggal, mengontrol dan mengobati infeksi kulit. ${ }^{26}$ Pencegahan GNAPS berkontribusi menurunkan insiden penyakit ginjal dan gagal ginjal di kemudian hari. ${ }^{21,26}$

\section{Ringkasan}

Glomerulonefritis akut pasca infeksi streptokokus ditandai oleh adanya kelainan klinis akibat proliferasi dan inflamasi glomerulus yang berhubungan dengan infeksi Streptococcus beta hemolyticus grup A tipe nefritogenik. Adanya periode laten antara infeksi dan kelainan-kelainan glomerulus menunjukkan proses imunologis memegang peran penting dalam mekanisme terjadinya penyakit. Diagnosis ditegakkan berdasarkan anamnesis, gejala klinis, pemeriksaan fisis, bakteriologis, serologis, imunologis, dan histopatologis. Pengobatan hanya bersifat suportif dan simtomatik. Prognosis umumnya baik, dapat sembuh sempurna pada lebih dari $90 \%$ kasus. Observasi jangka panjang diperlukan untuk membuktikan kemungkinan penyakit menjadi kronik.

\section{Daftar Pustaka}

1. Travis LB, Kalia. Acute nephritic syndrome. Dalam: Poslethwaite RJ, penyunting. Clinical pediatric nephrology. Edisi ke-2. Oxford: Butterworth-Heinemann, 1994. h. 201-9.

2. Sekarwana HN. Rekomendasi mutahir tatalaksana glomerulonefritis akut pasca streptokokus. Dalam: Aditiawati, Bahrun D, Herman E, Prambudi R, penyunting. Buku naskah lengkap simposium nefrologi VIII dan simposium kardiologi V. Ikatan Dokter Anak Indonesia Palembang, 2001. h. 141-62.

3. Noer MS. Glomerulonefritis. Dalam: Alatas H, Tambunan T, Trihono PP, Pardede SO, penyunting. Buku ajar nefrologi anak. Edisi ke-2. Jakarta: Balai Penerbit FKUI, 2002. h. 345-53.

4. Gauthier B,Edelmann CM, Barnett HL. Clinical acute glomerulonephritis. Dalam: Nephrology and urology for the pediatrician. Edisi ke-1. Boston: Little Brown \& Co, 1982. h. 109-22.

5. Travis LB. Acute post infections glomerulonephritis. Dalam: Rudolph AM, Hoffman JIE, Axelrod S, penyunting. Pediatrics. Edisi ke-18. Connecticut: Appleton \& Lange, 1987. h. 1169-71.

6. Langman CB. Hematuria. Dalam: Stockman III JA, penyunting. Difficult diagnosis in pediatrics.Philadelphia:
W.B.Saunders, 1990. h. 315-22.

7. Ramayati R dan Rusdidjas. Penanggulangan glomerulonefritis kronik pada anak. Disampaikan pada: Kongres Nasional Ilmu Kesehatan Anak X. Bukit Tinggi: Pancaran Ilmu, 1996. h. 105-19.

8. Ogle JW. Infections: bacterial and spirochaetal. Dalam: Hay WW, Grothuis JR, Hayward AR, Levin MJ, penyunting. Current pediatric diagnosis \& treatment. Edisi ke-13. Connecticut: Appleton \& Lange, 1997. h. 1003-6.

9. Svensson MD, Sjorbring U dan Bessen DE. Selective distribution of a high affinity plasminogen-binding site among group A Streptococci associated with impetigo. Infect and Immun 1999; 67:3915-20.

10. Bergstein JM. Condition particularly associated with hematuria. Dalam:Behrman RE, Kliegman RM, Jenson $\mathrm{HB}$, penyunting. Nelson texbook of pediatrics. Edisi ke16. Philadelphia: WB Saunders, 2000. h. 1577-82.

11. Jordan SC, Lemire JM. Acute glomerulonefritis diagnosis and treatment. Pediatr Clin North Am 1982; 29:85773 .

12. Lewy JE. Acute poststreptococal glomerulonephritis. Pediatr Clin North Am 1976; 23:751-9.

13. Makker SP. Glomerular disease. Dalam: Kher KK, Makker SP, penyunting. Clinical pediatric nephrology. New York: McGraw-Hill, 1992. h. 175-220.

14. Nordstrand A, McShan WM, Ferretti JJ, Holm SE dan Norgren M.Allele substitution of the streptokinase gene reduces the nephritogenic capacity of group A streptoccocal strain NZ131. Infect and Immun 2000; 68:1019-25.

15. Bisno AL.Non suppurative streptococcal sequelae: rheumatic fever and glomerulonephritis. Dalam: Mandell GL, Bennet JE, Dolin R, penyunting. Principles and practice of infectious diseases. Edisi ke-5. New York: Churchill Livingstone,2000. h. 2117-28.

16. Chapel H,Haeney M. Essential of clinical immunology. Edisi ke-2. Oxford: Blackwell Scientific Public, 1998. h.183-952.

17. Berner JJ. Effect of diseases on laboratory test .New York: J.B. Lippincott, 1983. h.123-7.

18. Rodriguez-Iturbe B. Postinfections glomerulonephritis. Am J Kidney Dis 2000; 35:46-8.

19. Fairley KF and Birch DF.Microscopic urinalysis in glomerulonephritis. Kidney Int 1991; 44:S-9-S-12.

20. Albar H, Rauf S, Daud D, Tanra A, Kaspan MF. Clinical edema and chest $\mathrm{x}$-ray findings in acute poststreptococcal glomerulonephritis. Dalam: Paediatr Indones 1997; 37:69-75.

21. Perlman LV, Herdman RC, Kleinman H, Vernier RL. Post streptococal glomerulonephritis, a ten year followup of an epidemic. JAMA 1965; 194:175-82.

22. Potter EV, Abidh S, Sharret AR dkk. Clinical healing two to six years after poststreptoccocal glomerulonephritis in Trinidad. New Engl J Med 1978; 298:767-72.

23. Nissenson AR, Mayon-White V, Potter EV, Earle D. Continued absence of clinical renal disease seven to 12 years after poststreptococcal acute glomerulonephritis in Trinidad. Am J Med 1979; 67:255-62. 
Sari Pediatri, Vol. 5, No. 2, September 2003

24. Hoy WE, Mathews JD, McCredie DA dkk. The multidimensional nature of renal disease: rate and associations of albuminuria in an aboriginal community. Kidney Int 1998; 54:1296-304.

25. Potter EV, Lipschultz SA, Abidh S, King TP, Earle DP. Twelve to seventeen-year follow up of patients with poststreptococal acute glomerulonephritis in trinidad. N Engl J Med 1982; 307:725-8.

26. White AV, Hoy AW, McCredie DA. Chilhood poststreptococal glomerulonephritis as a risk factor for chronic renal disease in later life. MJA 2001; 174:492631. 